\title{
The dynamics of sibling relationships with a down syndrome child
}

\author{
Ivena Nathania Victor, Hartanti, Mary Philia Elisabeth
}

\author{
Universitas Surabaya, Surabaya, Indonesia \\ libraryofivena@gmail.com, hartanti@staff.ubaya.ac.id, melisabeth@staff.ubaya.ac.id
}

Submitted : 12-02-2021, Revised : 29-04-2021, Accepted : 31-05-2021

\begin{abstract}
Siblings of special needs child are often seen as neglected children, especially when the special needs child needs more attention from their parents. This study aimed to find out the dynamics of sibling relationships with a down syndrome child. A phenomenological qualitative approach with data analysis of Interpretative Phenomenological Analysis (IPA) was chosen as the research method due to its suitability with the purpose of this study. The data were collected using in-depth semi-structured interviews on two biological older sisters (24 and 20 years old) of a boy with down syndrome (12 years old). The selection of subjects used a purposive sampling technique, which was based on the specified criteria. Three main themes were found in this study, namely (1) the functions of parents' role, (2) acceptance towards a sibling with Down syndrome, and (3) sibling relationship. The results showed that the parents' role in introducing the Down syndrome from the beginning helped the subjects accepted their sibling's special needs. The subjects' acceptance was expressed through their actions in supporting their younger sibling to become independent. Each subject also showed a sense of care in their own ways. Sibling relationships with a Down syndrome child were indicated by the existence of warmth, conflict, rivalry, role, engagement, stress, concern, and coping mechanisms.
\end{abstract}

Keywords: Acceptance; Down syndrome; Sibling relationship, The functions of parents' role

\section{Introduction}

The initial clinical description of Down syndrome was made by Down in 1866 and identified by Lejeune et al. as trisomy 21 in 1959 (Head et al., 2012). Down syndrome is a collection of symptoms exist due to a chromosomal abnormalities, precisely on chromosome 21 causing a Down syndrome person to have 47 chromosomes (Anjarwati \& Pusari, 2019). Ram \& Chinen (2011) stated that Down syndrome is the most common genetic disease and occurs with cognitive, heart, and gastrointestinal disorders, besides other clinical conditions. Therefore, Down syndrome is various symptoms either cognitive or physical occurs due to an abnormality in chromosome 21 .

The birth rate of newborns with Down syndrome was very high, to be precise 1:700 births worldwide or approximately 6,000 Down syndrome newborns each year (Centers for Disease Control and Prevention, 2014). In Indonesia, the number of children with Down syndrome aged $24-59$ months in 2010 was $0.12 \%$, in 2013 it increased to $0.13 \%$ and in 2018 it became $0.21 \%$ (Pemerintah Republik Indonesia, 2019). A Down syndrome person has an IQ around 50 (Santrock, 2011), may experience memory issues, and have limited vocabulary (Berk, 2013).

Limited abilities of a person with Down syndrome make them need support from others, especially from their core family. Therefore, the siblings usually will have responsibilities such as caretaking, serving, and helping their sibling to socialize with others (Floyd et al., 2009). Siblings of a special needs child are also described as "forgotten children" or "most neglected family members" (Nielsen et al., 2012). Moreover, when the parents need to provide additional care for their special needs child, the child's needs might become a priority that exceeds the needs of other family members and often interfere with the family activities (Graff et al., 2012). Also, the siblings of a special needs child usually will take over the primary caregiver role in the future, especially when the parents no longer 
capable or have passed away (Floyd et al., 2009). Most people with Down syndrome will have long-term relationships with their siblings because they can live over 60 years old and are usually nursed by their family members (National Down Syndrome Society, 2019).

Some research gaps were found from the results of previous related studies. Several subjects expressed that they felt joy because they had siblings with special needs, but others confessed that they felt sad (Ali \& Sarullah, 2010). Other research found that subjects tended not to worry too much about their sibling's Down syndrome condition, so they fight just like other siblings (Takataya et al., 2019). However, Schuntermann (2007) stated that the siblings had concerns about their Down syndrome sibling's condition both in the present and in the future.

The purpose of this research was to find out the dynamics of sibling relationships with a Down syndrome child because siblings are the ones who will have the longest relationship with the child. In addition, this study also aimed to answer some suggestions from previous research which encouraged further studies to be carried out on siblings of different gender (Cuskelly \& Gunn, 2003) and with older siblings (Moyson \& Roeyers, 2012).

Several factors that might affect the relationship between siblings and a Down syndrome child are the functions of parents' role (Sanders \& Morawska, 2018) and the acceptance of the siblings (Kübler-Ross, 1969). The functions of parents' role will influence how siblings accept their Down syndrome sibling, and the siblings' acceptance will affect their sibling relationship. The parents' role will continue to influence the sibling relationship that will last for a lifetime (Begum \& Blacher, 2011).

Functions of the parents' role include taking care of basic needs, emotional care, socialization, providing guidance, providing boundaries, teaching life skills and mentoring, being their child's advocate, supporting their child's education, and providing moral and spiritual guidance (Sanders \& Morawska, 2018). Acceptance of a special needs sibling includes the stages of denial, anger, bargaining, depression, and acceptance (Kübler-Ross, 1969). Sibling relationships with special needs children include warmth, conflict, rivalry, role, engagement, stress, concern, and coping mechanisms (Begum \& Blacher, 2011).

\section{Methods}

This study used a qualitative research design with an Interpretative Phenomenological Analysis (IPA) for data analysis. The data were collected via in-depth interviews and the subjects selection used the purposive sampling technique. The subjects criteria were as follows: older siblings who are at the age of emerging adulthood (18-25 years) based on Arnett (2006); living at home with their younger sibling with Down syndrome and their biological parents; the siblings and Down syndrome child have different gender; the Down syndrome child's age is between 6-12 years (Santrock, 2011). The age limitation for the Down syndrome child was selected because siblings have had enough experience together at that time and because the development delays of a Down syndrome child became more noticeable as they grew up.

The researcher's role was as an active listener who encouraged the subjects to share their life experiences. The interview questions were semi-structured and referred to aspects of the functions of parents' role (Sanders \& Morawska, 2018), acceptance (Kübler-Ross, 1969), and sibling relationship (Hodapp, 2011). The example of questions are "Are there any meaningful messages given by your parents regarding your sibling relationship with your Down syndrome sibling?"; "Usually, what causes you and your brother to fight?"; and "How do you deal with the stress from taking care of your Down syndrome sibling?".

To ensure research credibility, the entire conversations were recorded after getting permission from the subjects. This research also used data triangulation by interviewing the 
subjects' biological mother. To apply the transferability test in this study, researchers provided a systematic and detailed description of the research results, so this research may be easily understood by others and may be applied in similar situations. Dependability was tested when there was a consistency in the results of subjects' answers to identical questions that were asked at several different meetings. In addition, confirmability was tested by conducting consultations with expert researchers. In analyzing the data, this research used thematic data analysis by following these steps: organize data in a verbatim form; read the entire data; perform the coding; use coding to generate them in categories; represent themes; and make interpretations.

\section{Result and Discussion}

\section{Down syndrome}

The subjects in this study were older sisters aged 24 and 20 years old. Their parents have introduced them to their brother's Down syndrome condition since he was born 12 years ago. Previous research found that most siblings understood the Down syndrome condition of their siblings from their parents, doctors, or by performing their own research (Graff et al., 2012).

From the beginning, the subjects' mother decided that she would be open to other people about her child's special needs. The two subjects felt inspired by their mother's openness, so they never felt ashamed to tell others about their brother's condition. Their mother also mentioned how her daughters told their teachers and friends that they have a brother with Down syndrome. Santoso \& Handayani (2018) stated that siblings who have tolerated the Down syndrome condition since the beginning have received an explanation as early as possible from their parents. Here, it can be seen how big the parents' role is to the siblings' attitude towards their Down syndrome brother. This also shows the importance of introducing the Down syndrome condition to siblings from the very beginning.

\section{Functions of Parents' Role}

Even though the child with Down syndrome had been born in the family, the subjects' parents consistently took care of them and kept doing their role as parents. The affection and understanding that parents provided to the subjects made them feel that they were still part of the family. Their parents prepared for their breakfast, their school uniforms, and so on. This showed how their parents took care of their basic needs such as clothing, food, and affection.

Moreover, the subjects' parents showed a sense of care to the subjects' feelings by explaining that their younger brother was different and required extra care, from the beginning. Their parents didn't want them to get hurt when they realized that their brother needed more attention. Other than that, parents of the subjects also taught them about life skills including problem-solving. Their younger brother was nonverbal, so the parents tried to bring items that the boy might want and confirmed it with him. Both subjects imitated it in order to communicate with their Down syndrome brother. The parents also paid attention to their daughters' education by asking about school assignments and exams. Both subjects stated that those simple yet meaningful actions were what assured them that they were not being neglected.

There were also directions and boundaries given by their parents about the sibling relationships. Due to their brother's disabilities in several aspects, the subjects had been reminded to remain patient and tolerant of him. In addition, parents also provided moral and spiritual advice to them. They mentioned how they were constantly encouraged to help others, including their brother. This message had a strong impact on the subjects' sibling relationship with their Down syndrome brother. They also received spiritual messages, which 
reminded them to pray because they believed that God would help. This indicated that the parents played a significant role in forming the family members' values. On top of that, the functions of parents' role in the subjects' life became a protective factor in their sibling relationships.

\section{Sibling Relationship}

As stated before, a Down syndrome person usually would have limitations in their daily activities. Not only were both subjects aware of their brother's condition, but they also supported him to become independent in daily living activities. Barthel Index Activity of Daily Living (ADL) - a measuring instrument that scored individuals with disabilities related to their performance in daily life -, mentioned that there were several activities related to ADL, such as the ability to bathe, dress, and eat by themselves (Pecchia et al., 2014). Both subjects usually helped their brother to clean his body. They also had the initiative to teach their younger sibling to eat on his own. It wasn't easy for him at first. But, because of his siblings' persistence, he was finally able to eat independently.

The subjects' personality traits differences made them support their younger brother to become independent in their ways. The first subject stated that she was very close to her younger brother, even closer to him compared to her other sister. She even poured her heart out to her brother sometimes. Even though her brother might not understand what she said, she felt accepted and loved by her youngest sibling. This indicated that the first subject treated her younger brother just like a normal sibling. She also mentioned her brother's attitude that she disliked, which was being spoiled. She realized that he had been spoiled since he was born. However, the first subject didn't have any jealousy because she understood his position as the youngest member of the family. She stated that her patience was what helped her to become tolerant towards her brother's spoiled behavior.

On the other hand, the second subject felt a rivalry with her younger brother. She stated how she felt that her brother was rarely being asked to do anything, while she was given an additional task to take care of him. But, this envious feeling had decreased as she got older. Scharf et al. (2005) mentioned that sibling rivalry is usually more intense during adolescence than during adulthood. Even though she had jealousy, it doesn't mean that she didn't love her younger brother. She showed her love and care through disciplinary actions towards her brother to stimulate his independence. The second subject felt that her brother was a lazy boy, so she disciplined him by taking his gadgets and accompanying him to study. Her strength in the disciplinary attitude was confirmed by her mother's and sister's statements. Sharpe \& Rossiter (2002) stated that the characteristics of each child and their innate nature impact their sibling relationship.

They also experience conflicts just like any other siblings, mainly because of their brother's disobedience. Even so, the occurrence of conflicts doesn't mean a lack of warmth (Furman \& Buhrmester, 1985). The subjects' love for their brother was shown through their excitement when their brother did something that he wasn't able to do before. For example, when he counted from 1 to 10, both subjects happily praised him and gave him a high-five. This aligns with what Powell \& Ogle (1985) stated, that siblings feel joy and pleasure even at their special needs siblings' smallest accomplishments.

In terms of taking care of their younger brother, both subjects mentioned their stressful experiences. They usually felt most stressed when their brother interfered with their tasks. To cope with that, they remind themselves that their brother was indeed different. Both subjects thought that the large age distance made the special treatment received by their younger brother was normal, especially because he was the youngest child, the only boy in the family, and had Down syndrome. The ability to have this kind of awareness is called reflective thinking, which is one of the characteristics of cognitive changes in young adults 
(Santrock, 2011). Arnett (2006) stated that the ability to think reflectively appears when an individual's in the emerging adulthood stage. This kind of coping mechanism is called differentiation, meaning that they differentiated themselves from their special needs brother. Alfred Adler stated that differentiation is very important as a coping mechanism for siblings of a special needs child because when siblings view themselves differently from their special needs sibling, it will minimize the negative impact from experiencing differential parenting (Ansbacher, 1956). This also showed that the gender difference between the subjects and their Down syndrome sibling was one of the reasons that helped them to have the coping mechanism.

Sometimes, they also kept themselves busy with personal activities and avoided their brother when they were stressed. This indicated that the subjects used a coping mechanism with an emotional-focused behavioral approach, which is a coping mechanism performed by trying to control the emotional response to the pressing situation through engaging in activities (Sarafino \& Smith, 2014). Additionally, both subjects also had concerns regarding their brother's future and their future. An important message that their parents always reminded them about was to take care of their brother in the future. Schuntermann (2007) stated that siblings of children with special needs may have concerns both now and in the future, either related to themselves or their sibling. They also mentioned that they felt a burden because of having responsibilities to look after their special needs brother in the future. Previous research indicated that some siblings of special needs children may feel additional burdens and responsibilities in meeting their sibling's needs (Dyke et al., 2009).

Even though they have more roles as older siblings than others and have to take care of their younger brother, they performed the role very well. The subjects' mother confirmed that both of her daughters played an important role in supporting their brother to become independent because she couldn't discipline him due to her sorry feelings.

\section{Conclusions}

Several factors had an impact on the sibling relationships with a Down syndrome child, which were the functions of parents' role and the character of siblings. Parents' crucial role in introducing the Down syndrome from the start to the siblings helped them accept him. Getting siblings involved in various caregiving activities also helped them understand how to support their special needs sibling's development. Functions of parents' role (taking care of basic needs; emotional care; socialization; providing guidance; providing boundaries; teaching life skills and mentoring; being the child's advocate; supporting the children's education; and providing moral and spiritual guidance) were protective factors that helped siblings to have a positive sibling relationship.

Moreover, the subjects' character significantly affected their acceptance process and their sibling relationships. It also was a protective factor in creating a positive sibling relationship. Their positive perceptions of the Down syndrome condition helped them played their role as supportive siblings too. To deal with rivalry, stress, concern, and conflict with their Down syndrome sibling, the subjects used emotional-focused coping with cognitive and behavioral approaches. Both siblings performed their roles in their ways in supporting their brother to become independent. The first subject mostly used affection, while the second subject used disciplinary actions to stimulate Down syndrome sibling's development.

Several limitations of this study were the lack of the subjects' openness to their feelings related to negative experiences and there was no observation of the subjects due to the pandemic situation. Further researchers are suggested to build rapport with subjects to increase openness to various experiences and to investigate themes related to emotional regulation in sibling relationships with Down syndrome children. Other suggestions are to 
choose male siblings as subjects who have an age distance of fewer than 8 years with Down syndrome children; and also, those who have risk factors in the family conditions, for example, the parents who are overprotective or unable to accept the condition of special needs. Further research is also suggested to use several types of triangulation to increase the validity of the data.

\section{References}

Ali, M. M., \& Sarullah, S. (2010). Typical Siblings' acceptance of siblings with special needs. Procedia-Social and Behavioral Sciences, 9, 517-521.

Anjarwati, M. T., \& Pusari, R. W. (2019). Analisis Proses Penerimaan Diri Pada Ibu Terhadap Anak Down Syndrome. Seminar Nasional PAUD 2019, 127-134.

Ansbacher, H. (1956). The individual psychology of Alfred Adler, New York, et al.(Harper Colophon Books) 1956.

Arnett, J. J. (2006). Emerging Adulthood: Understanding the New Way of Coming of Age.

Begum, G., \& Blacher, J. (2011). The siblings relationship of adolescents with and without intellectual disabilities. Research in Developmental Disabilities, 32(5), 1580-1588.

Berk, L. E. (2013). Development through the lifespan 6th edition. Pearson.

Centers for Disease Control and Prevention. (2014). Facts about Down syndrome. Última Atualização Em, 15.

Cuskelly, M., \& Gunn, P. (2003). Sibling relationships of children with Down syndrome: Perspectives of mothers, fathers, and siblings. American Journal on Mental Retardation, 108(4), 234-244.

Dyke, P., Mulroy, S., \& Leonard, H. (2009). Siblings of children with disabilities: Challenges and opportunities. Acta Paediatrica, 98(1), 23.

Floyd, F. J., Purcell, S. E., Richardson, S. S., \& Kupersmidt, J. B. (2009). Sibling relationship quality and social functioning of children and adolescents with intellectual disability. American Journal on Intellectual and Developmental Disabilities, 114(2), 110-127.

Furman, W., \& Buhrmester, D. (1985). Children's perceptions of the qualities of sibling relationships. Child Development, 448-461.

Graff, C., Mandleco, B., Dyches, T. T., Coverston, C. R., Roper, S. O., \& Freeborn, D. (2012). Perspectives of adolescent siblings of children with Down syndrome who have multiple health problems. Journal of Family Nursing, 18(2), 175-199.

Head, E., Silverman, W., Patterson, D., \& Lott, I. T. (2012). Aging and down syndrome. Hindawi.

Hodapp, R. M. (2011). International review of research in developmental disabilities.

Kübler-Ross, E. (1969). Death and Dying. Simon and Schuster.

Moyson, T., \& Roeyers, H. (2012). 'The overall quality of my life as a sibling is all right, but of course, it could always be better'. Quality of life of siblings of children with intellectual disability: the siblings' perspectives. Journal of Intellectual Disability Research, 56(1), 87-101.

National Down Syndrome Society. (2019). What is Down syndrome?

Nielsen, K. M., Mandleco, B., Roper, S. O., Cox, A., Dyches, T., \& Marshall, E. S. (2012). Parental perceptions of sibling relationships in families rearing a child with a chronic condition. Journal of Pediatric Nursing, 27(1), 34-43.

Pecchia, L., Chen, L., Nugent, C., \& Bravo, J. (2014). Ambient Assisted Living and Daily Activities: 6th International Work-Conference, IWAAL 2014, Belfast, UK, December 2-5, 2014, Proceedings (Vol. 8868). Springer.

Pemerintah Republik Indonesia. (2019). Kementerian Kesehatan Republik Indonesia. Riset Kesehatan Dasar. 
Powell, T. H., \& Ogle, P. A. (1985). Brothers and Sisters: A Special Part of. Paul H.

Ram, G., \& Chinen, J. (2011). Infections and immunodeficiency in Down syndrome. Clinical \& Experimental Immunology, 164(1), 9-16.

Sanders, M. R., \& Morawska, A. (2018). Handbook of parenting and child development across the lifespan. Springer.

Santoso, D. K., \& Handayani, P. (2018). Psychological Adjustment Effectivity in Elder Siblings of Children with Down Syndrome. Ijds: Indonesian Journal Of Disability Studies, 5(2), 231-240.

Santrock, J. W. (2011). Life-span development 13th edition. New York: McGraw-Hill. Schunk, DH (2005). Self-Regulated Learning: The Educational Legacy of Paul R. Pintrich. Educational Psychologist, 40(2), 85-94.

Sarafino, E. P., \& Smith, T. W. (2014). Health psychology: Biopsychosocial interactions. John Wiley \& Sons.

Scharf, M., Shulman, S., \& Avigad-Spitz, L. (2005). Sibling relationships in emerging adulthood and in adolescence. Journal of Adolescent Research, 20(1), 64-90.

Schuntermann, P. (2007). The sibling experience: Growing up with a child who has pervasive developmental disorder or mental retardation. Harvard Review of Psychiatry, 15(3), 93-108.

Sharpe, D., \& Rossiter, L. (2002). Siblings of children with a chronic illness: A metaanalysis. Journal of Pediatric Psychology, 27(8), 699-710.

Takataya, K., Mizuno, E., Kanzaki, Y., Sakai, I., \& Yamazaki, Y. (2019). Feelings of siblings having a brother/sister with Down syndrome. Archives of Psychiatric Nursing, 33(4), $337-346$. 
